\title{
Identification of Factors Affecting Food Productivity Improvement in Kalimantan Using Nonparametric Spatial Regression Method
}

\author{
Sifriyani $^{1}$, Suyitno ${ }^{1} \&$ Rizki. N. A. ${ }^{2}$ \\ ${ }^{1}$ Statistics Study Programme, Department of Mathematics, Faculty of Mathematics and Natural Sciences, \\ Mulawarman University, Samarinda, Indonesia. \\ ${ }^{2}$ Mathematics Education Study Programme, Faculty of Teacher Training and Education, Mulawarman University, \\ Samarinda, Indonesia. \\ Correspondence: Sifriyani, Statistics Study Programme, Department of Mathematics, Faculty of Mathematics \\ and Natural Sciences, Mulawarman University, Samarinda, Indonesia. E-mail: sifriyani@fmipa.unmul.ac.id
}

Received: August 8, 2019

Accepted: October 23, 2019

Online Published: October 24, 2019

doi:10.5539/mas.v13n11p103

URL: https://doi.org/10.5539/mas.v13n11p103

\begin{abstract}
Problems of Food Productivity in Kalimantan is experiencing instability. Every year, various problems and inhibiting factors that cause the independence of food production in Kalimantan are suffering a setback. The food problems in Kalimantan requires a solution, therefore this study aims to analyze the factors that influence the increase of productivity and production of food crops in Kalimantan using Spatial Statistics Analysis. The method used is Nonparametric Spatial Regression with Geographic Weighting. Sources of research data used are secondary data and primary data obtained from the Ministry of Agriculture and the Central Statistics Agency. The total area used is 56 regencies/cities in Kalimantan. The results show that there are 13 factors affect food productivity in Kalimantan. These factors are the number of agricultural business households, the number of workers in agriculture, the amount of rice production, rice field area, rice field harvest area, irrigation network area, area of each region, total area based on altitude class, area based on slope/slope class, economic growth rate, Gross Regional Domestic Product, Regional Development Index and Population Density. The best model is obtained using the geographical weighting of the Gaussian kernel function with the cross-validation value 5,65. The criteria for the goodness of the model with the number of knots 3 and order $m=1$ have $\mathrm{R}^{2}$ value of $97,19 \%$ and the value of AIC is 2,43 .
\end{abstract}

Keywords: food productivity, spatial statistics, nonparametric, geographic weighting, Kalimantan

\section{Introduction}

Kalimantan is facing severe quite complex problems in agriculture. The food production showed a shortage of 223 thousand tons from the needs of 458 tons annually. Various kinds of problems and inhibiting factors that cause the independence of food production in Kalimantan are experiencing a setback. The food problems in Kalimantan requires a solution, therefore this study aims to analyze the factors that influence the increase of productivity and production of food crops in Kalimantan using Spatial Statistics Analysis. The method used is Nonparametric Spatial Regression with Geographic Weighting.

This study aims to find the supporting factors and inhibitors of food crop productivity and production in each regency/city on the island of Kalimantan. The next objective is to analyze strategies, formulate effective alternative strategies to increase the production of the food crops sub-sector and to contribute to the Department of Food Security in each regency/city of Kalimantan Province.

Statistical analysis used is one of the methods in spatial statistics, namely the Nonparametric Regression method with Geographic Weighting (Sifriyani, Haryatmi, I.N Budiantara, \& Gunardi, 2017), (Sifriyani, S. H. Kartiko, I. N. Budiantara \& Gunardi, 2015). This method is a development of nonparametric regression that considers geographical or spatial factors. Differences influence increased productivity and production of food crops in environmental and geographical characteristics between locations of observation in each regency/city in Kalimantan.

This problem resulted in each region will have different supporting and inhibiting factors for each region. This method is very suitable because it will produce a different model for each regency/city that we examine. This 
method will produce one statistical modeling for each district/city, so we will find supporting factors and obstacles that are different for each district/city.

\section{Data Source and Method}

\subsection{Data Source}

The data used in this study are secondary data and Primary data obtained from the Ministry of Agriculture and the Central Statistics Agency. The area used is 56 regencies/cities in Kalimantan. The research variables used are respond variables and predictor variables. The response variable is rice crop productivity (y) in 56 regencies/cities in Kalimantan. Predictor variables that are thought to affect y are:

1. Number of agricultural business households $\left(x_{1}\right)$

2. Number of workers in agriculture $\left(x_{2}\right)$

3. Amount of rice production $\left(x_{3}\right)$

4. Rice field area $\left(x_{4}\right)$

5. Rice field harvested area $\left(x_{5}\right)$

6. Irrigation network area $\left(x_{6}\right)$

7. Area of each region $\left(x_{7}\right)$

8. Area-based on height class $\left(x_{8}\right)$

9. Area size by slope class $\left(x_{9}\right)$

10. Economic Growth Rate $\left(x_{10}\right)$

11. Gross Regional Domestic Product $\left(x_{11}\right)$

12. Regional Development Index $\left(x_{12}\right)$

13. Population density $\left(x_{13}\right)$

\subsection{Research Method}

The method used in this research is Nonparametric Spatial Regression with Geographic Weighting. The analysis step was carried out in 5 stages. They are model estimation [15], selection of optimal knot points (Sifriyani, Haryatmi, I.N Budiantara, \& Gunardi, 2017), testing the suitability of the model hypothesis (Sifriyani, I.N. Budiantara, S.H. Kartiko \& Gunardi, 2018), Simultaneous hypothesis testing (Sifriyani, 2019) and testing the significance of parameters partially (Fotheringham, A.S, Brunsdon, C \& Charlton, M., 2012) Map Mapping using GIS. The steps of Nonparametric Spatial Regression with Geographic Weighting modeling are as follows:

1. Identification response variable $y$ and predictor variables

2. Descriptive statistical analysis from each response variable $y$ and predictor variables

3. Data pattern analysis between response variable $y$ with each predictor variable

4. Spatial heterogeneity Test with Breusch-Pagan method

5. Goodness of Fit Test

6. Calculating the Eucliden distance between the $\mathrm{i}$ location located at the coordinates $\left(u_{i}, v_{i}\right)$ to location $\mathrm{j}$ which is located in the coordinates $\left(u_{i}, v_{i}\right)$

7. Nonparametric Spline Analysis by Determining the optimum knot point.

8. Determining weighting for Nonparametric Spatial Regression with Geographic Weighting modeling.

9. Obtaining an estimator of the Nonparametric Spatial Regression with Geographic Weighting.

10. Interpretation of model.

11. simultaneous hypothesis Test.

12. Partial significance test for each Districts/City.

13. Mapping 56 areas in Kalimantan based on factors that influence Productivity Improvement of Food in Kalimantan.

14. Making conclusions. 


\section{Result and Discussion}

\subsection{Data Exploration of Food Productivity in Kalimantan}

Figure 1 presents the distribution map for Food Productivity Data of 56 regencies/cities in Kalimantan until 2019. Average food productivity in Kalimantan is $37.19 \mathrm{Ku} / \mathrm{Ha}$, where the highest food productivity is in Malinau Regency, North Kalimantan Province, which is $89,54 \mathrm{Ku} / \mathrm{Ha}$ and the lowest food productivity was in Palangka Raya City, Central Kalimantan Province. Figure 1 also shows the distribution map of rice productivity having the amount of rice productivity ranging from 22.03 Tons / Ha to 89.54 Tons / Ha.

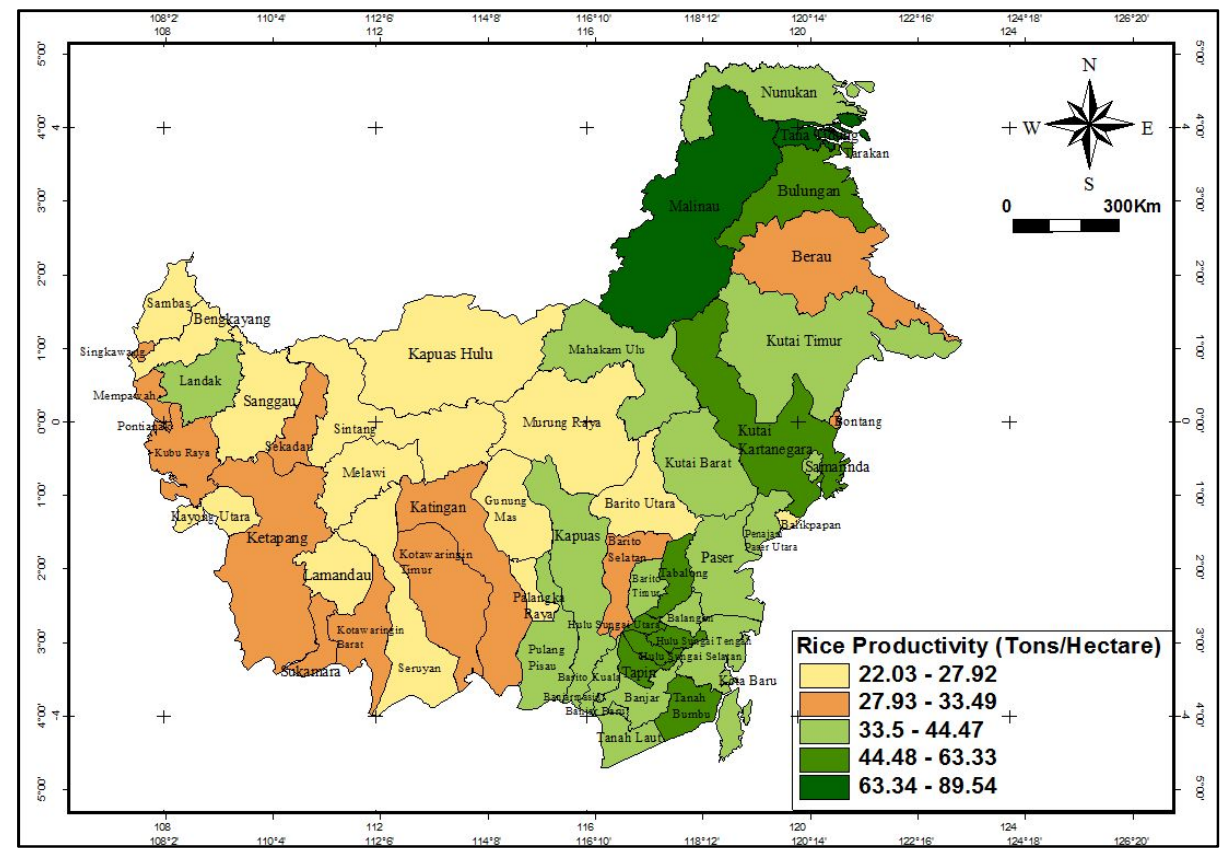

Figure 1. Distribution Maps for 56 Food District/City Food Productivity Data in Kalimantan.

Data Source for 2019

Based on Figure 1, the most significant food productivity is around $63.34 \mathrm{Ku} / \mathrm{Ha}$ up to $89.54 \mathrm{Ku} / \mathrm{Ha}$, then the regencies/cities included in this group are Malinau Regency and Tana Tidung Regency. As for the smallest food productivity around $22.03 \mathrm{Ku} / \mathrm{Ha}$ up to $27.92 \mathrm{Ku} / \mathrm{Ha}$ and regencies/cities included in this group are Balikpapan City, Barito Utara Regency, Murung Raya Regency, Gunung Mas Regency, Palangka Raya City , Kapuas Hulu Regency, Sintang Regency, Melawi Regency, Seruyan Regency, Lamandau Regency, North Kayong Regency, Sanggau Regency, Bengkayang Regency and Sambas Regency.
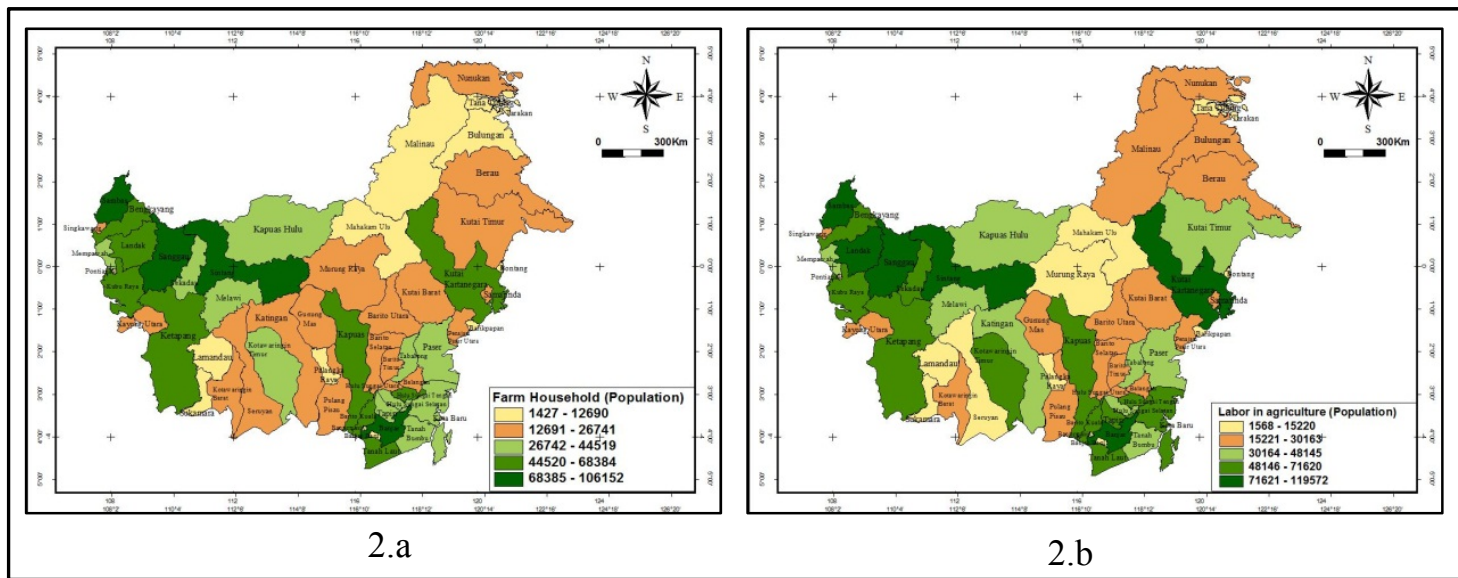

Figure 2. Spatial Diversity Map for Labor Data in Agriculture in 56 regencies/cities in Kalimantan.

Data Source for 2019 
Figure 2 explains the map of the spatial diversity of labor in agriculture in 56 regencies/cities in Kalimantan which is divided into two parts: the number of agricultural business households shown in 2.a and the number of workers in agriculture shown in 2.b. The most significant number of agricultural business households is between 68,385 people up to 106,512 people, and regencies/cities included in this group are Banjar District, Sintang Regency, Sanggau Regency, and Sambas Regency. The smallest number of agricultural business households are between 1,427 people up to 12,690 people, regencies/cities included in this group are Pontianak City, Lamandau Regency, Sukamara Regency, Palangka Raya City, Banjarbaru City, Banjarmasin City, Malinau Regency, Mahakam Ulu Regency, Bulungan Regency, Balikpapan City, Tana Tidung Regency, Tarakan City, and Bontang City.

The most significant number of workers shown on map 2.b. between 71,621 people up to 119,572 people, regencies/cities included in this group are Kutai Kartanegara Regency, Banjar City, Sintang Regency, Sanggau Regency, Kubu Raya Regency, Landak Regency, and Sambas Regency. The smallest number of workers is between 1,568 people up to 15,220 people, and regencies/cities included in this group are Tana Tidung Regency, Tarakan City, Bontang City, Balikpapan City, Mahakam Ulu Regency, Murung Raya Regency, Banjarbaru City, Lamandau Regency, Regency Sukamara, Banjarmasin City and Pontianak City.

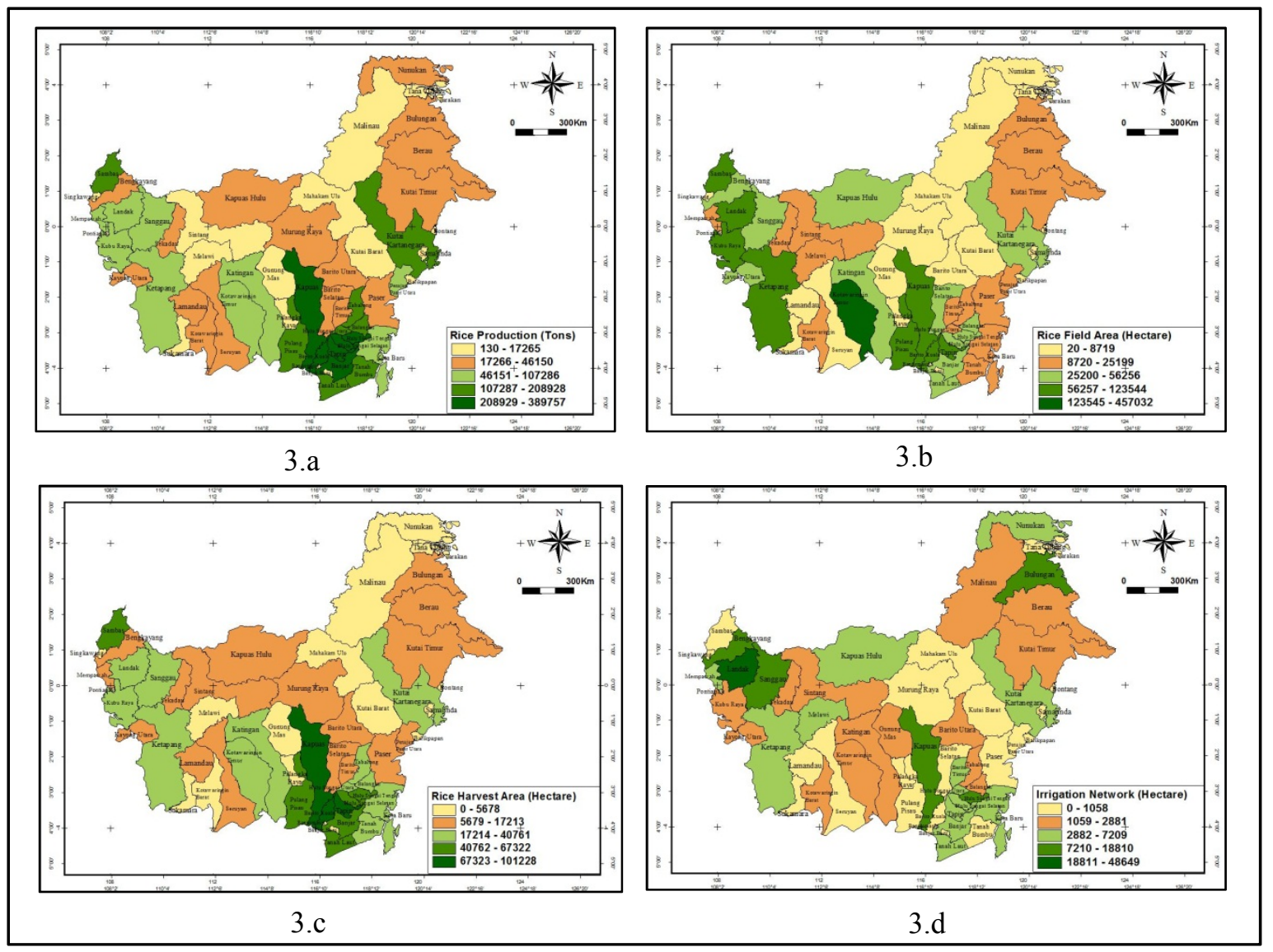

Figure 3. Spatial Diversity Map for Potential Land Resources in 56 regencies/cities in Kalimantan.

Data Source for 2019

Figure 3 explains the spatial diversity map of potential land resources in 56 districts/cities in Kalimantan which is divided into four parts. They are the amount of rice production shown in 3.a, the area of agricultural land shown in 3.b, the area of rice harvest shown in 3.c and irrigation network area shown in 3.d.

The largest amount of rice production is between 208,929 tons to 389,757 tons. Regencies/cities included in this group are Kapuas Regency, Barito Kuala Regency, Banjar City, Tapin Regency, Hulu Sungai Selatan Regency, and Hulu Sungai Tengah Regency. The smallest amount of rice production is between 130 tons to 17,265 tons, regencies/cities included in this group are Tana Tidung Regency, Tarakan City, Malinau Regency, Mahakam Ulu Regency, West Kutai Regency, Bontang City, Samarinda City, Balikpapan City, Regency Gunung Mas, 
Palangka Raya City, Sintang Regency, Banjarbaru City, Banjarmasin City, Pontianak City, and Singkawang City.

The largest agricultural land area is between 123,545 Ha up to 457,032 Ha. Regencies/cities included in this group are Kotawaringin Timur Regency and Kapuas Regency. While the smallest agricultural land area is between $20 \mathrm{Ha}$ to $8,719 \mathrm{Ha}$, regencies/cities included in this group are Singkawang City, Pontianak City, Lamandau Regency, Sukamara Regency, Seruyan Regency, Palangka Raya City, Gunung Mas Regency, Banjarmasin City, City Banjarbaru, Murung Raya Regency, Mahakam Ulu Regency, North Barito Regency, Samarinda City, Balikpapan City, Bontang City, Malinau Regency, Tana Tidung Regency, Nunukan Regency and Tarakan City.

The largest rice harvested area is between 67,323 hectares up to 101,228 hectares. Regencies/ cities included in this group are Kapuas Regency, Barito Kuala Regency, Banjar City, and Tapin Regency. The smallest rice harvest area is between 0 to 5,678 Ha, regencies/cities included in this group are Singkawang City, Pontianak City, Melawi Regency, Sukamara Regency, Gunung Mas Regency, Palangka Raya City, Banjarmasin City, Banjarbaru City, Hulu Sungai Regency South, West Kutai Regency, Balikpapan City, Mahakam Ulu Regency, Samarinda City, Bontang City, Malinau Regency, Nunukan Regency, Tana Tidung Regency and Tarakan City

The largest irrigation network area is between 18,811 Ha up to 48,649 Ha. Regencies/cities included in this group are the Landak District. Whereas the smallest irrigation network area is between 0 to $1,058 \mathrm{Ha}$. Regencies/Cities included in this group are Sambas Regency, Singkawang City, Pontianak City, Lamandau Regency, Seruyan Regency, Sukamara Regency, Pulang Pisau Regency, Palangka Raya City, Regency Barito Kuala, Banjarmasin City, Banjarbaru City, Tanah Bumbu Regency, Paser Regency, South Barito Regency, Balikpapan City, Penajam Paser Utara Regency, West Kutai Regency, Mahakam Ulu Regency, Murung Raya Regency, Bontang City, Samarinda City, Tarakan City and Regency Tana Tidung.

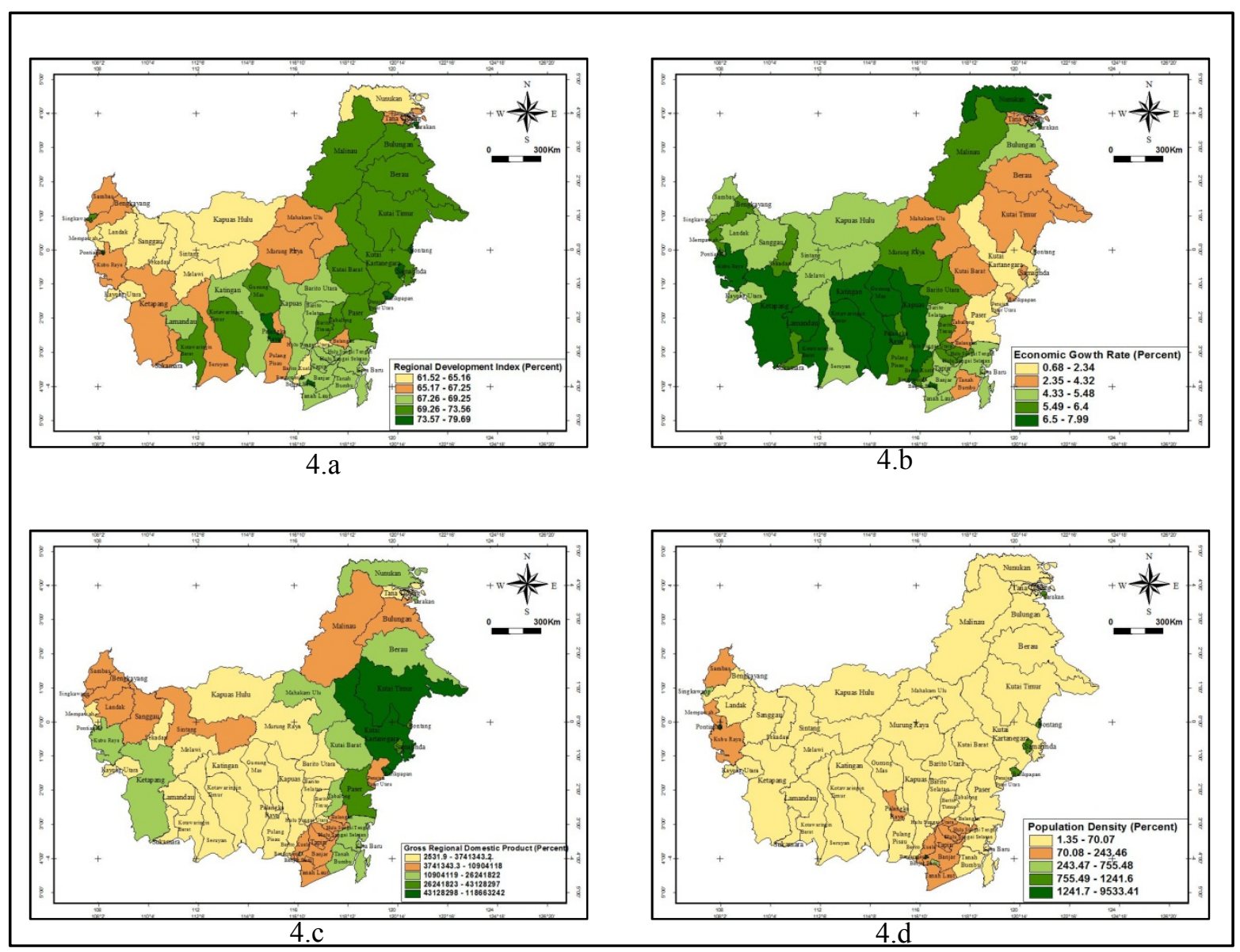

Figure 4. Map of Spatial Diversity for Economic Conditions and Population Density in 56 Regencies/Cities in Kalimantan. Data Source for 2019 
Figure 4 explains the spatial diversity map of economic conditions and population density in 56 regencies/cities in Kalimantan which is divided into four parts. They are the regional development index shown in 4.a, the Economic Growth Rate shown in 4.b, Gross Regional Domestic Product shown in 4.c and Population Data shown in 4.d.

The highest regional development index is between $73.57 \%$ to $79.69 \%$. Regencies/cities included in this group are Banjarmasin City, Banjarbaru City, Balikpapan City, Samarinda City, Bontang City, Palangka Raya City, Pontianak City, and Tarakan City whereas the lowest regional development index is between $61.52 \%$ to $65.16 \%$. Regencies/cities included in this group are Mempawah Regency, Landak Regency, Sanggau Regency, North Kayong Regency, Sekadau Regency, Sintang Regency, Melawi Regency, Kapuas Hulu Regency, Barito Kuala Regency, Hulu Sungai Utara Regency, Nunukan Regency.

The highest economic growth rate is between $6.5 \%$ to $7.99 \%$. Regencies/cities included in this group are Nunukan Regency, Tarakan City, Banjarbaru City, Kapuas Regency, Gunung Mas Regency, Palangka Raya City, Katingan Regency, East Kotawaringin Regency, West Kotawaringin Regency, Lamandau Regency, Ketapang Regency, and Kubu Raya Regency. The lowest economic growth rate is between $0.68 \%$ to $2.34 \%$, Regencies/Cities included in this group are Kutai Kartanegara Regency, Bontang City, North Penajam Paser Regency, and Paser Regency.

The highest Gross Regional Domestic Product is between 43,128,298 Million to 118,663,242 Million Rupiah. Regencies/cities included in this group are East Kutai Regency, Bontang City, Kutai Kartanegara Regency, and Balikpapan City whereas the lowest GRDP is between 2,531.9 Million Rupiah to 3,741,343.2 Million Rupiah. Regencies/cities included in this group are Tana Tidung Regency, Mempawah Regency, Sekadau Regency, North Kayong Regency, Melawi Regency, Seruyan Regency, Lamandau Regency, West Kotawaringin Regency, Sukamara Regency, East Kotawaringin Regency, Katingan Regency, Gunung Mas Regency, Palangka Raya City, Pulang Pisau Regency, Kapuas Regency, South Barito Regency, East Barito Regency, Hulu Sungai Utara Regency, North Barito Regency and Murung Raya Regency.

The highest population density was between $1,241.7 \%$ to $9,533.41 \%$. Regencies/cities included in this group are Pontianak City and Banjarmasin City whereas the lowest population density is between $1.35 \%$ to $70.07 \%$. Regencies/cities included in this group are Nunukan Regency, Tana Tidung Regency, Bulungan Regency, Malinau Regency, Berau Regency, East Kutai Regency, Kutai Kartanegara Regency, West Kutai Regency, Mahakam Ulu Regency, North Penajam Paser Regency, Paser Regency, Regency Kapuas Hulu, Murung Raya Regency, North Barito Regency, Tabalong Regency, East Barito Regency, Balangan Regency, Kotabaru Regency, Tanah Bumbu Regency, South Barito Regency, Kapuas Regency, Pulang Pisau Regency, Katingan Regency, Gunung Mas Regency, Sintang Regency, Regency Melawi, Sekadau Regency, Sanggau Regency, Landak Regency, Kayong Utara Regency, Lamandau Regency, Sukamara Regency, West Kotawaringin Regency, Seruyan Regency and East Kotawaringin Regency.

\subsection{Spatial Heterogeneity and Geographic Weighting}

The Breusch-Pagan test is employed to identify spatial heterogeneity. The effect of spatial heterogeneity results in non-homogeneous error variance, and there are indications of grouping regions, because of that nonparametric regression with geographical weighting is used. The best geographical weighting is the optimum bandwidth value. In this study, Cross-Validation (CV) is used to determine the optimum bandwidth. Table 1 shows the results of spatial heterogeneity testing using the Breusch-Pagan test and the optimum bandwidth values.

Table 1. Results of Analysis of Nonparametric Spatial Regression with Geographic Weighting

\begin{tabular}{|c|c|c|c|c|}
\hline \multirow[b]{2}{*}{$\begin{array}{l}\text { Spatial } \\
\text { Heterogeneity } \\
\text { Test }\end{array}$} & Breusch-Pagan Test & df & $p$-Value & Decision \\
\hline & 44,099 & 26 & 0,014 & $\begin{array}{l}\text { There is effect of } \\
\text { spatial } \\
\text { heterogeneity }\end{array}$ \\
\hline \multirow{3}{*}{$\begin{array}{l}\text { CV Values for } \\
\text { Weighted } \\
\text { Function }\end{array}$} & WeightedFunction & $\begin{array}{l}\text { Optimal } \\
\text { Bandwidth }\end{array}$ & Cross Validation (CV) & $\begin{array}{l}\text { Generalized } \mathrm{CV} \\
\text { (GCV) }\end{array}$ \\
\hline & Kernel Gaussian & 1,977 & 5,649 & 2,67 \\
\hline & Kernel Bisquare & 7,696 & 6,730 & 3,02 \\
\hline \multirow[t]{2}{*}{ Kriteria model } & Method & $\begin{array}{l}\text { Number of } \\
\text { Knot Point }\end{array}$ & $\begin{array}{l}\text { Coefficient } \\
\text { Determination } \mathrm{R}^{2}\end{array}$ & AIC \\
\hline & Orde $m=1$ & 3 & 97,192 & 2,43 \\
\hline
\end{tabular}


Based on Table 1, it can be concluded that rice productivity data has a spatial heterogeneity effect with the optimum bandwidth value obtained using the Gaussian Kernel weighting function, which is 1.977 . This is showed by the smallest GCV value and CV value. In addition, the R-Squared value of the model with the orde $\mathrm{m}$ $=1$ is 97.192. All of those results indicate that the predictor variable number of agricultural business households $\left(x_{1}\right)$, the number of workers in agriculture $\left(x_{2}\right)$, the amount of rice production $\left(x_{3}\right)$, wetland area $\left(x_{4}\right)$, wetland harvest area $\left(x_{5}\right)$, irrigation network area $\left(x_{6}\right)$, area of each region $\left(x_{7}\right)$, area based on height class $\left(x_{8}\right)$, area based on slope class/slope $\left(x_{9}\right)$, Economic Growth Rate $\left(x_{10}\right)$, Gross Regional Domestic Product $\left(x_{11}\right)$, Regional Development Index $\left(x_{12}\right)$ and population density $\left(x_{13}\right)$ are able to explain the variable rice productivity (y) of $97.192 \%$ and the result of $2.808 \%$ explained by other factors have not been studied.

\subsection{Nonparametric Spatial Regression Method with Geographic Weighting}

The method used in this research is Nonparametric Spatial Regression with Geographic Weighting. The step analysis was carried out using five stages: estimation of the model (Sifriyani, S. H. Kartiko, I. N. Budiantara \& Gunardi, 2018), selection of optimal knot points (Sifriyani, Haryatmi, I.N Budiantara, \& Gunardi, 2017), testing the suitability hypothesis of the model (Sifriyani, I.N. Budiantara, S.H. Kartiko \& Gunardi, 2018), simultaneous hypothesis testing (Sifriyani, 2019) and testing the significance of parameters partially (Fotheringham, A.S, Brunsdon, C \& Charlton, M., 2002).

\section{Model Estimation and Knot Point Selection}

Modeling Nonparametric Spatial Regression with Geographic Weighting has the advantage of having knots in the model. With the knots, the resulted model will follow the pattern of relationships by the behavior of the data. The optimal knots can be seen from the minimum GCV value. The GCV method is generally defined as follows (Eubank, R. L., 1999), (Green, P.J. dan Silverman, B.W., 1994).

$$
\operatorname{GCV}\left(K_{1}, K_{2}, \ldots, K_{r}\right)=\frac{\operatorname{MSE}\left(K_{1}, K_{2}, \ldots, K_{r}\right)}{\left(n^{-1} \operatorname{trace}\left[I-A\left(K_{1}, K_{2}, \ldots, K_{r}\right)\right]\right)^{2}},
$$

where

$$
\operatorname{MSE}\left(K_{1}, K_{2}, \ldots, K_{r}\right)=n^{-1} \sum_{i=1}^{n}\left(y_{i}-\hat{f}\left(x_{i}\right)\right)^{2}
$$

The results of the nonparametric spatial regression method with a geographical weighting obtained GCV values by orde $m=1$ and $K_{p h}=3$ shown in Table 2 .

Table 2. Knot Point and GCV Values for Variables $x_{1}, x_{2}, x_{3}, x_{4}, x_{5}$ and $x_{6}$

\begin{tabular}{llllllll}
\hline No. & $x_{1}$ & $x_{2}$ & $x_{3}$ & $x_{4}$ & $x_{5}$ & $x_{6}$ & GCV \\
\hline \multirow{3}{*}{1} & 2474,25 & 3521,5 & 41222,5 & 2748,04 & 3928,08 & 46409,52 & \\
& 2059,846 & 38489,07 & 486,49 & 972,98 & 18486,62 & 489,1503 & 48,14878 \\
& 1423258 & 0,7531 & 0,8262 & 3,4578 & 1189139 & 2375746 & \\
\multirow{2}{*}{2} & 2474,25 & 3521,5 & 42269,75 & 2748,04 & 3928,08 & 46409,52 & \\
& 2059,846 & 39501 & 486,49 & 972,98 & 18973,11 & 489,1503 & 48,18781 \\
& 1423258 & 0,7531 & 0,8262 & 3,5309 & 1189139 & 2375746 & \\
3 & 2474,25 & 3521,5 & 40175,25 & 2748,04 & 3928,08 & 46409,52 & \\
& 2059,846 & 37477,15 & 486,49 & 972,98 & 18000,13 & 489,1503 & 48,22603 \\
& 1385804 & 0,7531 & 0,8262 & 3,3847 & 1189139 & 2375746 & \\
4 & 2474,25 & 3521,5 & 39128 & 2748,04 & 3928,08 & 46409,52 & \\
& 2059,846 & 36465,23 & 486,49 & 972,98 & 17513,64 & 489,1503 & 48,33122 \\
\hline
\end{tabular}


Table 3. Knot Point and GCV Values for Variables $x_{7}, x_{8}, x_{9}, x_{10}, x_{11}, x_{12}$ and $x_{13}$

\begin{tabular}{lllllllll}
\hline No. & $x_{7}$ & $x_{8}$ & $x_{9}$ & $x_{10}$ & $x_{11}$ & $x_{12}$ & $x_{13}$ & GCV \\
\hline \multirow{3}{*}{1} & 4026,27 & 7922,54 & 148188,3 & 1255,24 & 2490,48 & 46959,12 & 1047,923 & \\
& 923,6306 & 16240,92 & 24097,5 & 48195 & 915705 & 37454,17 & 74908,34 & 48,14878 \\
& 45093602 & 61,7017 & 61,8834 & 68,4246 & 96,6706 & 191,9912 & 3623,533 & \\
& 4026,27 & 7922,54 & 152084,5 & 1255,24 & 2490,48 & 48194,36 & 1047,923 & \\
2 & 923,6306 & 16666,4 & 24097,5 & 48195 & 939802,5 & 37454,17 & 74908,34 & 48,18781 \\
& 46280209 & 61,7017 & 61,8834 & 68,6063 & 96,6706 & 191,9912 & 3718,853 & \\
& 4026,27 & 7922,54 & 144292 & 1255,24 & 2490,48 & 45723,88 & 1047,923 & \\
3 & 923,6306 & 15815,44 & 24097,5 & 48195 & 891607,5 & 37454,17 & 74908,34 & 48,22603 \\
& 43906995 & 61,7017 & 61,8834 & 68,2429 & 96,6706 & 191,9912 & 3528,212 & \\
& 4026,27 & 7922,54 & 140395,7 & 1255,24 & 2490,48 & 44488,64 & 1047,923 & \\
4 & 923,6306 & 15389,96 & 24097,5 & 48195 & 867510 & 37454,17 & 74908,34 & 48,33122 \\
& 42720388 & 61,7017 & 61,8834 & 68,0612 & 96,6706 & 191,9912 & 3432,892 & \\
\hline
\end{tabular}

Table 2 and Table 3 obtained the optimum knots points with a GCV value of 48.148 . The optimum knot points are:

$$
\begin{aligned}
& K_{11}=2474,25 ; K_{12}=3521,5 ; K_{13}=41222,5 ; K_{21}=2748,04 ; K_{22}=3928,08 ; \\
& K_{23}=46409,52 ; K_{31}=4026,27 ; K_{32}=7922,54 ; K_{33}=148188,3 ; K_{41}=1255,24 ; \\
& K_{42}=2490,48 ; K_{43}=46959,12 ; K_{51}=1047,923 ; K_{52}=2059,846 ; K_{53}=38489,07 ; \\
& K_{61}=486,49 ; K_{62}=972,98 ; K_{63}=18973,11 ; K_{71}=498,150 ; K_{72}=923,63 ; K_{63}=16240,92 ; \\
& K_{81}=24097,5 ; K_{82}=48195 ; K_{83}=915705 ; K_{91}=37454,17 ; K_{92}=74908,34 ; K_{93}=1423258 \\
& K_{101}=0,7531 ; K_{102}=0,8262 ; K_{103}=3,4578 ; K_{111}=1189139 ; K_{112}=2375746 ; K_{113}=45093602 \\
& K_{121}=61,701 ; K_{122}=61,883 ; K_{123}=3623,53 ; K_{131}=96,67 ; K_{132}=191,99 ; K_{133}=3623,53
\end{aligned}
$$

So, in general, the nonparametric spatial regression model with a geographical weight is as equation 3

$$
\begin{aligned}
\hat{y}_{i}=\hat{\beta}_{0}( & \left.u_{i}, v_{i}\right)+\hat{\beta}_{11}\left(u_{i}, v_{i}\right) x_{1 i}+\hat{\beta}_{21}\left(u_{i}, v_{i}\right) x_{2 i}+\hat{\beta}_{31}\left(u_{i}, v_{i}\right) x_{3 i}+\hat{\beta}_{41}\left(u_{i}, v_{i}\right) x_{4 i}+\ldots+\hat{\beta}_{131}\left(u_{i}, v_{i}\right) x_{13 i} \\
& +\hat{\delta}_{12}\left(u_{i}, v_{i}\right)\left(x_{1 i}-K_{11}\right)_{+}+\hat{\delta}_{22}\left(u_{i}, v_{i}\right)\left(x_{2 i}-K_{21}\right)_{+}+\ldots+\hat{\delta}_{132}\left(u_{i}, v_{i}\right)\left(x_{13 i}-K_{131}\right)_{+} \\
& +\hat{\delta}_{13}\left(u_{i}, v_{i}\right)\left(x_{1 i}-K_{12}\right)_{+}+\hat{\delta}_{23}\left(u_{i}, v_{i}\right)\left(x_{2 i}-K_{22}\right)_{+}+\ldots+\hat{\delta}_{133}\left(u_{i}, v_{i}\right)\left(x_{13 i}-K_{132}\right)_{+} \\
& +\hat{\delta}_{14}\left(u_{i}, v_{i}\right)\left(x_{1 i}-K_{13}\right)_{+}+\hat{\delta}_{24}\left(u_{i}, v_{i}\right)\left(x_{2 i}-K_{23}\right)_{+}+\ldots+\hat{\delta}_{134}\left(u_{i}, v_{i}\right)\left(x_{6 i}-K_{133}\right)_{+}
\end{aligned}
$$

Where $\mathrm{i}=1,2, \ldots, 56$ is the explanation of the area following the regency/city discussed in this study.

\section{Simultaneous Parameters Signification test}

The simultaneous testing hypothesis of the Nonparametric Spatial Regression model with a Geographic Weight is

$H_{0}: \beta_{11}\left(u_{i}, v_{i}\right)=\beta_{12}\left(u_{i}, v_{i}\right)=\ldots=\beta_{l m}\left(u_{i}, v_{i}\right)=\delta_{1, m+h}\left(u_{i}, v_{i}\right)=\delta_{1, m+h}\left(u_{i}, v_{i}\right)=\ldots=\delta_{l, m+r}\left(u_{i}, v_{i}\right)$

$H_{1}$ : at least one $\beta_{p k}\left(u_{i}, v_{i}\right) \neq 0$ atau $\delta_{p, m+h}\left(u_{i}, v_{i}\right) \neq 0$,

Statistical test (Sifriyani, 2019) to test the hypothesis of $H_{0}$ against $H_{1}$ is 


$$
V^{*}=\frac{\left(\frac{\mathbf{y}^{\mathrm{T}} M\left(u_{i}, v_{i}\right) \mathbf{y}}{\operatorname{tr}\left(\left(\mathbf{I}-\mathbf{B}_{\mathbf{\omega}}\right)^{\mathrm{T}}\left(\mathbf{I}-\mathbf{B}_{\mathbf{\omega}}\right)\right)}\right)}{\left(\frac{\mathbf{y}^{\mathrm{T}} D\left(u_{i}, v_{i}\right) \mathbf{y}}{\operatorname{tr}\left((\mathbf{I}-\xi)^{\mathrm{T}}(\mathbf{I}-\xi)\right)}\right)}
$$

Based on the statistic result $V=12,406>F_{(0,05 ; 53 ; 19)}=1,992$ and $p-$ value $=0,000<\alpha=0,05$ so it can be decided that $H_{0}$ is rejected and the conclusion of the parameters of food productivity data are influenced by geographical weighting $\left(u_{i}, v_{i}\right)$.

\section{Significance Test of Partial Parameters}

The following hypothesis is a significance test of partial parameters.

$\mathrm{H}_{0}: \beta_{p k}\left(u_{i}, v_{i}\right)=0$ and $\delta_{p, m+h}\left(u_{i}, v_{i}\right)=0$

with $p=1,2, \ldots, 8 ; k=1 ; h=1,2,3 ; i=1,2, \ldots, 56$ Regency $/$ City

$\mathrm{H}_{1}$ : at least there is one $\beta_{p k}\left(u_{i}, v_{i}\right) \neq 0$ dan $\delta_{p, m+h}\left(u_{i}, v_{i}\right) \neq 0$

with $p=1,2, \ldots, 8 ; k=1 ; h=1,2,3 ; i=1,2, \ldots, 56$ Regency $/$ City

Statistics Test for partial test on the models used the formula by Fotheringham (Fotheringham, A.S, Brunsdon, C \& Charlton, M., 2002) as follow:

$$
t=\frac{\hat{\tilde{\eta}}\left(u_{i}, v_{i}\right)}{S E\left(\hat{\tilde{\eta}}\left(u_{i}, v_{i}\right)\right)},
$$

Where $S E\left(\hat{\tilde{\eta}}\left(u_{i}, v_{i}\right)\right)=\sqrt{g_{k k}}$ and $g_{k k} \quad$ is a diagonal element of $k+1$ from matrix $\left(Q^{\mathrm{T}} \mathrm{W}\left(u_{i}, v_{i}\right) Q\right)^{-1} \hat{\sigma}^{2}\left(u_{i}, v_{i}\right)$.

Statistics test for multivariable spline truncated nonparametric regression model in GWR in equation (5) will follow the distribution of $t$ with degrees of freedom $(n-1)$ and significance level of $\alpha$, then the decision taken will reject $\mathrm{H}_{0}$ if $|t|>t_{\left(\frac{\alpha}{2},(n-1)\right)}$. Figure 5 and table 4 present the result of partial significance parameter test.

Table 4 is the results of grouping by regency/city which is influenced by predictor variables. Table 4 describes that group 1 Nunukan Regency, Tana Tidung Regency, Malinau Regency, Bulungan Regency, Kutai Kartanegara Regency, West Kutai Regency, Penajam Paser Utara Regency, Balikpapan City, Samarinda City, Mahakam Ulu Regency, Kapuas Hulu Regency, Melawi Regency, North Kayong Regency, Landak Regency, Sambas Regency, Singkawang City, Banjarmasin City, Banjar City, Pontianak City are influenced by the number of agricultural business households, the number of workers in agriculture, the wide of rice production, rice field area, rice harvest area, area irrigation network, regency/city area, the area based on altitude class, area based on slope class, Economic Growth Rate, Gross Regional Domestic Product, regional development index and population density. 
Table 4. Grouping Significant Variables for Food Productivity Data in Kalimantan

\begin{tabular}{|c|c|c|c|}
\hline No. & Regencies/Cities & Significant Variable & Group \\
\hline \multirow{19}{*}{1} & Nunukan & \multirow{9}{*}{$\begin{array}{l}\text { the number of agricultural business households } \\
\left(x_{1}\right) \text {, labor in agriculture }\left(x_{2}\right) \text {, the amount of } \\
\text { rice production }\left(x_{3}\right) \text {, the area of rice fields } \\
\left(x_{4}\right) \text {, the area of rice harvesting }\left(x_{5}\right) \text {, the } \\
\text { irrigation network }\left(x_{6}\right) \text {, the area of a }\end{array}$} & \multirow{19}{*}{1} \\
\hline & Tana Tidung & & \\
\hline & Bulungan & & \\
\hline & Malinau & & \\
\hline & Kutai Kartanegara & & \\
\hline & Kutai Barat & & \\
\hline & Penajam Paser Utara & & \\
\hline & Balikpapan & & \\
\hline & Samarinda & & \\
\hline & Mahakam Ulu & \multirow{5}{*}{$\begin{array}{l}\text { regency/city }\left(x_{7}\right) \text {, the area based on height } \\
\text { class }\left(x_{8}\right) \text {, the area according to slope / slope } \\
\text { class }\left(x_{9}\right) \text {, economic growth rate }\left(x_{10}\right) \text {, } \\
\text { Gross Regional Domestic Product }\left(x_{11}\right) \text {, } \\
\text { regional development index }\left(x_{12}\right), \text { and } \\
\text { population density }\left(x_{13}\right)\end{array}$} & \\
\hline & Kapuas Hulu & & \\
\hline & Melawi & & \\
\hline & Kayong Utara & & \\
\hline & Landak & & \\
\hline & Sambas & & \\
\hline & Singkawang & & \\
\hline & Banjarmasin & & \\
\hline & Banjar & & \\
\hline & Pontianak & & \\
\hline \multirow{2}{*}{2} & Mempawah & \multirow{2}{*}{$x_{1}, x_{2}, x_{3}, x_{4}, x_{5}, x_{6}, x_{7}, x_{8}, x_{9}, x_{11}$} & \multirow{2}{*}{2} \\
\hline & Sanggau & & \\
\hline \multirow{2}{*}{3} & Sekadau & $x_{1}, x_{2}, x_{3}, x_{4}, x_{5}, x_{6}, x_{7}, x_{8}, x_{9}$ & \multirow{2}{*}{3} \\
\hline & & $x_{11}, x_{12}, x_{13}$ & \\
\hline \multirow{2}{*}{4} & Katingan & $x_{1}, x_{2}, x_{3}, x_{4}, x_{5}, x_{6}, x_{7}, x_{8}, x_{9}$ & \multirow{2}{*}{4} \\
\hline & Kubu Raya & $x_{11}, x_{13}$ & \\
\hline \multirow{2}{*}{5} & Barito Timur & $x_{1}, x_{2}, x_{3}, x_{4}, x_{5}, x_{6}, x_{9}, x_{10}, x_{11}$ & \multirow{2}{*}{5} \\
\hline & & $x_{12}, x_{13}$ & \\
\hline \multirow{2}{*}{6} & Murung Rava & $x_{1}, x_{2}, x_{3}, x_{4}, x_{5}, x_{6}, x_{9}, x_{11}, x_{12}$ & \multirow{2}{*}{6} \\
\hline & & $x_{13}$ & \\
\hline \multirow{5}{*}{7} & Bontang & \multirow{5}{*}{$\begin{array}{l}x_{1}, x_{2}, x_{3}, x_{5}, x_{6}, x_{7}, x_{8}, x_{9}, x_{10}, \\
x_{11}, x_{12}, x_{13}\end{array}$} & \multirow{5}{*}{7} \\
\hline & Paser & & \\
\hline & Tabalong & & \\
\hline & Kota Baru & & \\
\hline & Barito Kuala & & \\
\hline \multirow{2}{*}{8} & Kanuas & $x_{1}, x_{2}, x_{3}, x_{5}, x_{6}, x_{7}, x_{8}, x_{9}, x_{10}$ & \multirow{2}{*}{8} \\
\hline & & $x_{12}, x_{13}$ & \\
\hline \multirow{2}{*}{9} & Kutai Timur & $x_{1}, x_{2}, x_{3}, x_{5}, x_{6}, x_{7}, x_{8}, x_{9}, x_{11}$, & \multirow{2}{*}{9} \\
\hline & Sintang & $x_{12}, x_{13}$ & \\
\hline \multirow{2}{*}{10} & Tapin & $x_{1}, x_{2}, x_{3}, x_{5}, x_{6}, x_{7}, x_{9}, x_{10}, x_{11}$ & \multirow{2}{*}{10} \\
\hline & & $x_{12}, x_{13}$ & \\
\hline
\end{tabular}




\begin{tabular}{|c|c|c|c|}
\hline 11 & Berau & $x_{1}, x_{2}, x_{3}, x_{5}, x_{6}, x_{8}, x_{9}, x_{10}, x_{11}$ & 11 \\
\hline 12 & $\begin{array}{l}\text { Gunung Mas } \\
\text { Palangka Raya }\end{array}$ & $x_{1}, x_{2}, x_{3}, x_{5}, x_{6}, x_{8}, x_{9}, x_{11}, x_{13}$ & 12 \\
\hline 13 & Barito Selatan & $\begin{array}{l}x_{1}, x_{2}, x_{3}, x_{5}, x_{6}, x_{9}, x_{10}, x_{11}, x_{12}, \\
x_{13}\end{array}$ & 13 \\
\hline 14 & Balangan & $x_{1}, x_{2}, x_{3}, x_{6}, x_{9}, x_{10}, x_{11}, x_{12}, x_{13}$ & 14 \\
\hline 15 & Barito Utara & $x_{1}, x_{2}, x_{3}, x_{9}, x_{11}, x_{12}, x_{13}$ & 15 \\
\hline 16 & Bengkayang & $x_{2}, x_{3}, x_{4}, x_{8}, x_{9}, x_{11}$ & 16 \\
\hline 17 & Hulu Sungai Utara & $x_{2}, x_{3}, x_{5}, x_{6}, x_{7}, x_{8}, x_{9}$ & 17 \\
\hline 18 & $\begin{array}{l}\text { Hulu Sungai Tengah } \\
\text { Tanah Bumbu }\end{array}$ & $\begin{array}{l}x_{2}, x_{3}, x_{5}, x_{6}, x_{7}, x_{8}, x_{9}, x_{10} \\
x_{11}, x_{12}, x_{13}\end{array}$ & 18 \\
\hline 19 & Pulang Pisau & $x_{2}, x_{3}, x_{5}, x_{6}, x_{7}, x_{8}, x_{9}, x_{10}, x_{13}$ & 19 \\
\hline 20 & Tanah Laut & $x_{2}, x_{3}, x_{6}, x_{7}, x_{9}, x_{11}, x_{13}$ & 20 \\
\hline 21 & $\begin{array}{l}\text { Lamandau } \\
\text { Kotawaringin Barat }\end{array}$ & $x_{3}$ & 21 \\
\hline 22 & Sukamara & $x_{3}, x_{4}$ & 22 \\
\hline 23 & Ketapang & $x_{3}, x_{4}, x_{5}, x_{6}, x_{7}, x_{8}, x_{9}, x_{10}, x_{12}$ & 23 \\
\hline 24 & Seruyan & $x_{3}, x_{4}, x_{6}, x_{13}$ & 24 \\
\hline 25 & Kotawaringin Timur & $x_{3}, x_{5}, x_{6}, x_{7}, x_{13}$ & 25 \\
\hline 26 & Hulu Sungai Selatan & $x_{3}, x_{5}, x_{6}, x_{7}, x_{8}, x_{9}, x_{10}, x_{11}, x_{12}, x_{13}$ & 26 \\
\hline 27 & Banjar Baru & $x_{3}, x_{5}, x_{6}, x_{7}, x_{9}, x_{11}, x_{13}$ & 27 \\
\hline
\end{tabular}

\subsection{Discussion Identification of Factors Affecting Food Productivity in Kalimantan}

Figure 5 is the result of testing the significance of partial parameters. Based on the picture, it can be explained the factors that influence food productivity in 56 regencies/cities in Kalimantan.

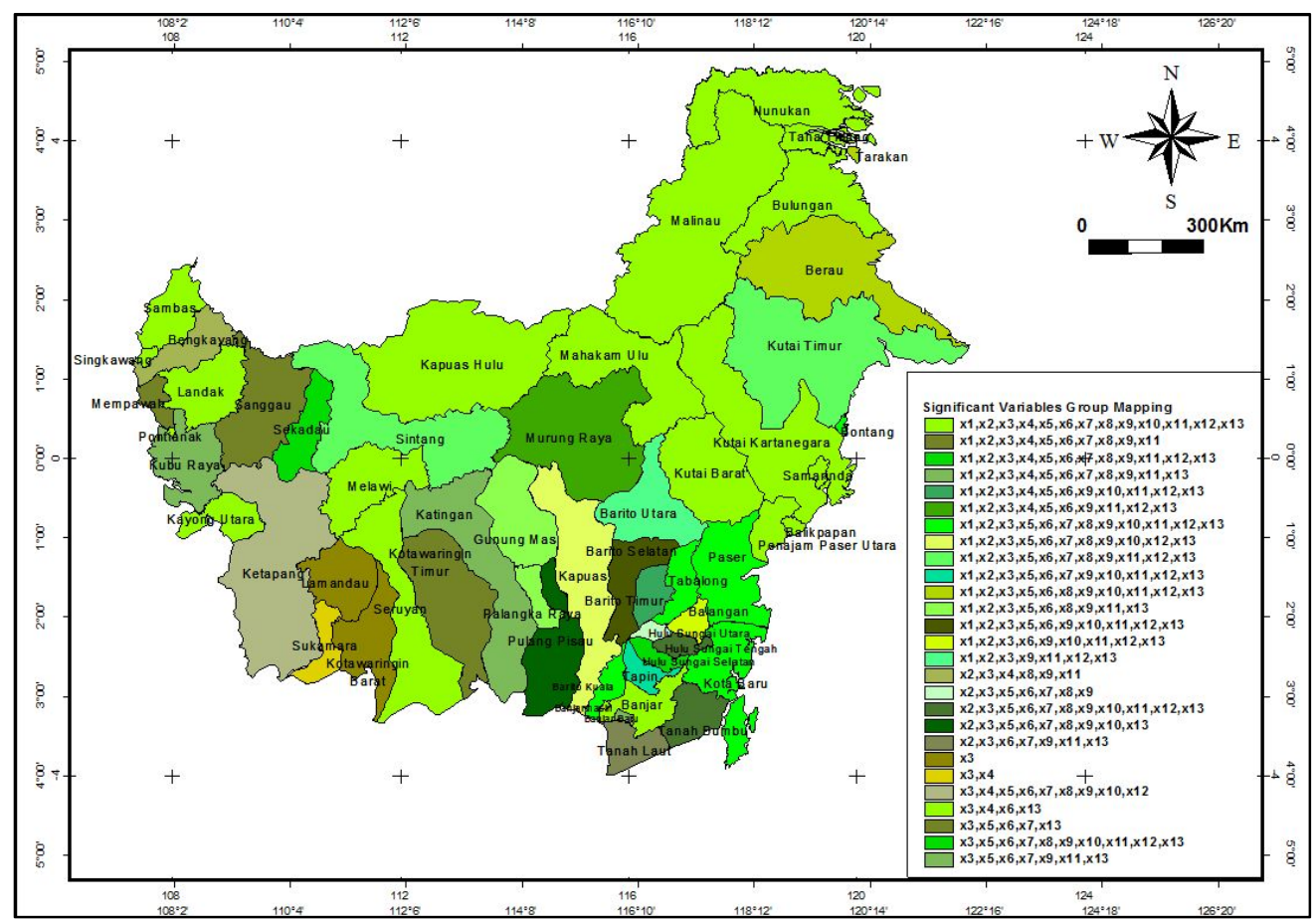

Figure 5. Mapping of Significant Predictor Variables 
The following explanation is for the first ten groups in Figure 5.

1. Food Productivity in Nunukan Regency, Tana Tidung Regency, Malinau Regency, Bulungan Regency, Kutai Kartanegara Regency, West Kutai Regency, North Penajam Paser Regency, Balikpapan City, Samarinda City, Mahakam Ulu Regency, Kapuas Hulu Regency, Melawi Regency, Kayong Regency North, Landak Regency, Sambas Regency, Singkawang City, Banjarmasin City, Banjar City, Pontianak City are influenced by many agricultural business households, the number of workers in agriculture, rice production, rice field area, rice harvest area, irrigation network area, regency/city area, area by height class, area by slope class, Economic Growth Rate, Gross Regional Domestic Product, regional development index and population density.

2. Food productivity in Mempawah and Sanggau districts are influenced by the number of agricultural business households, food productivity in, and workers in agriculture, rice production rate, rice field area, rice harvest area, irrigation network area, area of regency/city, area based on altitude class, the area according to slope/slope class and Gross Regional Domestic Product.

3. Food productivity in Sekadau Regency is influenced by the number of agricultural business households, the number of workers in agriculture, rice production rate, rice field area, rice harvest area, irrigation network area, area of regency/city, area based on height class, total area according to slope class, Gross Regional Domestic Product index of regional development and population density.

4. Food productivity in Katingan and Kubu Raya Regency are influenced by the number of agricultural business households, the number of workers in agriculture, rice production rate, rice field area, rice harvest area, irrigation network area, area of regency/city, total area based on height class, area according to slope class, Gross Regional Domestic Product and population density.

5. Food productivity in East Barito Regency is influenced by the number of agricultural business households, the number of workers in agriculture, rice production, rice field area, rice harvest area, irrigation network area, area according to slope class, Economic Growth Rate, Gross Regional Domestic Product, regional development index and population density.

6. Food productivity in Murung Raya Regency is influenced by the number of agricultural business households, the number of workers in agriculture, rice production rate, rice filed area, rice harvest area, irrigation network area, area according to slope class, Economic Growth Rate, Gross Regional Domestic Product, regional development index and population density.

7. Food Productivity in Bontang City, Paser Regency, Tabalong Regency, Kota Baru Regency, Barito Kuala Regency are influenced by agricultural business households, the number of workers in agriculture, rice production rate, rice harvested area, irrigation network area, wide area regency/city, area based on height class, area by slope / slope class, Economic Growth Rate, Gross Regional Domestic Product, regional development index and population density.

8. Food productivity in Kapuas Regency is influenced by the number of agricultural business households, the number of workers in agriculture, rice production rate, rice harvest area, irrigation network area, regency/city area, the area based on height class, area according to slope class, Economic Growth Rate, regional development index and population density.

9. Food Productivity in East Kutai and Sintang Regency are influenced by the number of agricultural business households, the number of workers in agriculture, rice production rate, rice harvest area, irrigation network area, area of regency/city, area based on height class, total area according to slope class, Gross Regional Domestic Product, regional development index and population density.

10. Food Productivity in Tapin District is influenced by the number agricultural business households, the number of workers in agriculture, rice production rate, rice harvest area, irrigation network area, regency/city area, area based on height class, area by class slope, Economic Growth Rate, Gross Regional Domestic Product, regional development index and population density.

\section{Conclusion}

The results of research on the identification of factors that affect Food Productivity in 56 regencies/cities in Kalimantan obtained 27 groups which are described in Table 4 and Figure 5. Each district/city has significant factors that are different from other regions. Nonparametric spatial regression method identified 13 factors that affect food productivity in Kalimantan: the number of agricultural business households, the number of workers in agriculture, the amount of rice production, the area of rice fields, the area of harvested rice fields, the area of 
irrigation networks, area of each region, total area based on altitude class, area based on slope/slope class, economic growth rate, Gross Regional Domestic Product, Regional Development Index and Population Density.

\section{Acknowledgment}

This article was funded and supplied by the PNBP grant of Faculty of Mathematics and Natural Sciences 2019 Fiscal year.

\section{References}

BPS Kalimantan Timur. (2019). East Kalimantan Province in Figures. Central Statistics Agency. East Kalimantan Province.

BPS Kalimantan Barat. (2019). West Kalimantan Province in Figures. Central Statistics Agency. West Kalimantan Province.

BPS Kalimantan Selatan. (2019). South Kalimantan Province in Figures. Central Statistics Agency of South Kalimantan Province.

BPS Kalimantan Utara. (2019). North Kalimantan Province in Figures. Central Statistics Agency. North Kalimantan Province.

BPS Kalimantan Tengah. (2019). Central Kalimantan Province in Figures. Central Statistics Agency. Central Kalimantan Province.

BPS Indonesia. (2018). Human Development Index. CPM. Indonesia.

BPS Indonesia. (2018). Export Commodity Analysis 2012 -2018 Agriculture, Industry and Mining Sectors. CPM. Indonesia.

Food Security Agency of the Ministry of Agriculture. (2019). Directory of Development of Food Consumption. Indonesian Food Security Agency.

Food Security Agency of the Ministry of Agriculture. (2018). Food Security Statistics. Indonesian Food Security Agency.

Food Security Agency of the Ministry of Agriculture. (2019). Food Security in Infographics. Indonesian Food Security Agency.

Eubank, R. L. (1999). Nonparametric Regression and Spline Smoothing, Marcel Dekker, New York.

Fotheringham, A.S, Brunsdon, C \& Charlton, M. (2002). Geographically Weighted Regression: The Analysis of Spatially Varying Relationships, John Wiley \& Sons Ltd, England.

Green, P.J. dan Silverman, B.W. (1994). Nonparametric Regression and Generalized Linear Model. Chapman \& Hall: London. https://doi.org/10.1007/978-1-4899-4473-3

Sifriyani, Haryatmi, I.N Budiantara, \& Gunardi. (2017). Geographically Weighted Regression with Spline Approach. Far East Journal of Mathematical Sciences, 101(6), 1183-1196. https://doi.org/10.17654/MS101061183

Sifriyani, S. H. Kartiko, I. N. Budiantara \& Gunardi. (2018). Development of Nonparametric Geographically Weighted Regression Using Truncated Spline Approach. Songklanakarin Journal of Science and Technology, 40(4), 909-920.

Sifriyani, I.N. Budiantara, S.H. Kartiko \& Gunardi. (2018). A New Method of Hypothesis Test for Truncated Spline Nonparametric Regression Influenced by Spatial Heterogeneity and Application. Abstract and Applied Analysis. https://doi.org/10.1155/2018/9769150

Sifriyani. (2019). Simultaneous Hypothesis Testing of Multivariable Nonparametric Spline Regression in the GWR model. International Journal of Statistics and Probability, 8(4). https://doi.org/10.5539/ijsp.v8n4p32

\section{Copyrights}

Copyright for this article is retained by the author(s), with first publication rights granted to the journal.

This is an open-access article distributed under the terms and conditions of the Creative Commons Attribution license (http://creativecommons.org/licenses/by/4.0/). 